\title{
SÚČASNÉ RUSKÉ DIVADLO: SPOMIENKY NA BUDÚCNOSŤ
}

ZUZANA SPODNIAKOVÁ

Ústav divadelnej a filmovej vedy Centra vied o umení Slovenskej akadémie vied, Bratislava

Abstrakt: Rok 2019 bol v Rusku vyhlásený za Rok divadla. Divadlo si tu totiž nielen zachováva svoje významné postavenie, ale predstavuje čoraz aktívnejší nástroj komunikácie tvorcov a verejnosti. Štúdia sa v súvislosti s tým zameriava na pomenovanie výrazných tém a foriem súčasného ruského divadla. Odhal'uje moderné vývinové tendencie ruskej divadelnej kultúry, ktoré reflektujú minulost’ i súčasnost̉ a kladú naliehavú otázku o budúcnosti - personálnej, národnej i svetovej. Autorka prostredníctvom vybraných inscenácií a divadelných osobností prezentovaných na festivale Zlatá maska 2019 zachytáva nové prístupy tvorcov ku klasickým dramatickým a prozaickým dielam, aj spôsob reflektovania dejín Ruska, jeho národných symbolov a mýtov v inscenovaných textoch súčasných ruských dramatikov.

Klúčové slová: súčasné ruské divadlo, ruská dráma, ruská próza, Zlatá maska 2019, Rok divadla, dejiny Zväzu sovietskych socialistických republík

\section{Pohl'ad do budúcnosti}

Súčasné ruské divadlo sa s čoraz väčšou naliehavostou pozerá do budúcnosti, pričom v jeho vnímaní sa zrkadlia nielen obavy z nej, ale aj strach o budúcnost' samotnú, o to, či vôbec príde. Prítomnost’ pre postavy častokrát znamená zároveň koniec. Budúcnost' si nevedia predstavit', je pre nich nedosiahnutel'nou utópiou, preto sa utiekajú k minulosti. Napríklad v hre Michaila Durnenkova ${ }^{1}$ Utopija (Utópia) ${ }^{2}$ je rozpadajúcej sa manželskej dvojici a ich synovi ponúknutá možnost' vrátit’ sa k predošlému životu. Na ceste $\mathrm{k}$ vytvoreniu novej budúcnosti z minulosti sa však točia v kruhu skladajúcich a rozkladajúcich sa obrazov, z ktorého sa nedokážu vymanit'. Podla autora je hra „o strachu z budúcnosti, o strachu zo života, o snahe nájst’ bezpečné presvedčenie

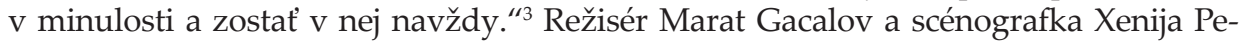
retruchinová ${ }^{2}$ zvolili pre vytvorenie realistických i metaforických obrazov súčasného života originálny princíp. Pre uvedomenie si prázdnoty nenaplneného života odobrali divadlu jeden rozmer - z trojrozmerného zážitku divákom dovolili sledovat' príbeh len v 2D. Herci hrajú od začiatku do konca ležiac, resp. sediac na zemi a publikum vidí po celý čas iba ich odraz v zrkadle zavesenom nad javiskom. Nemôže ich z neho vyslo-

\footnotetext{
${ }^{1}$ Michail Durnenkov získal na festivale Zlatá maska 2019 za túto hru cenu v kategórii najlepší dramatik.

2 Teatr Nacij (Divadlo Národov), Moskva, premiéra 20. 6. 2018.

${ }^{3}$ DURNENKOV, M. In ABAKŠONOK, N. - CAREVSKAJA, J. (eds.). Zolotaja maska. Rossijskaja nacional'naja teatral'naja premija i festival'. 25. [Bulletin $\mathrm{k}$ festivalu]. Moskva : Zolotaja maska. Rossijskaja nacional'naja teatral'naja premija i festival', 2019, s. 95.

${ }^{4}$ Rovnaký tandem spolupracoval v tomto divadle aj na úspešnej inscenácii Dychanie (Dýchanie), ktorá získala Zlatú masku 2018 za najlepšiu scénografiu.
} 


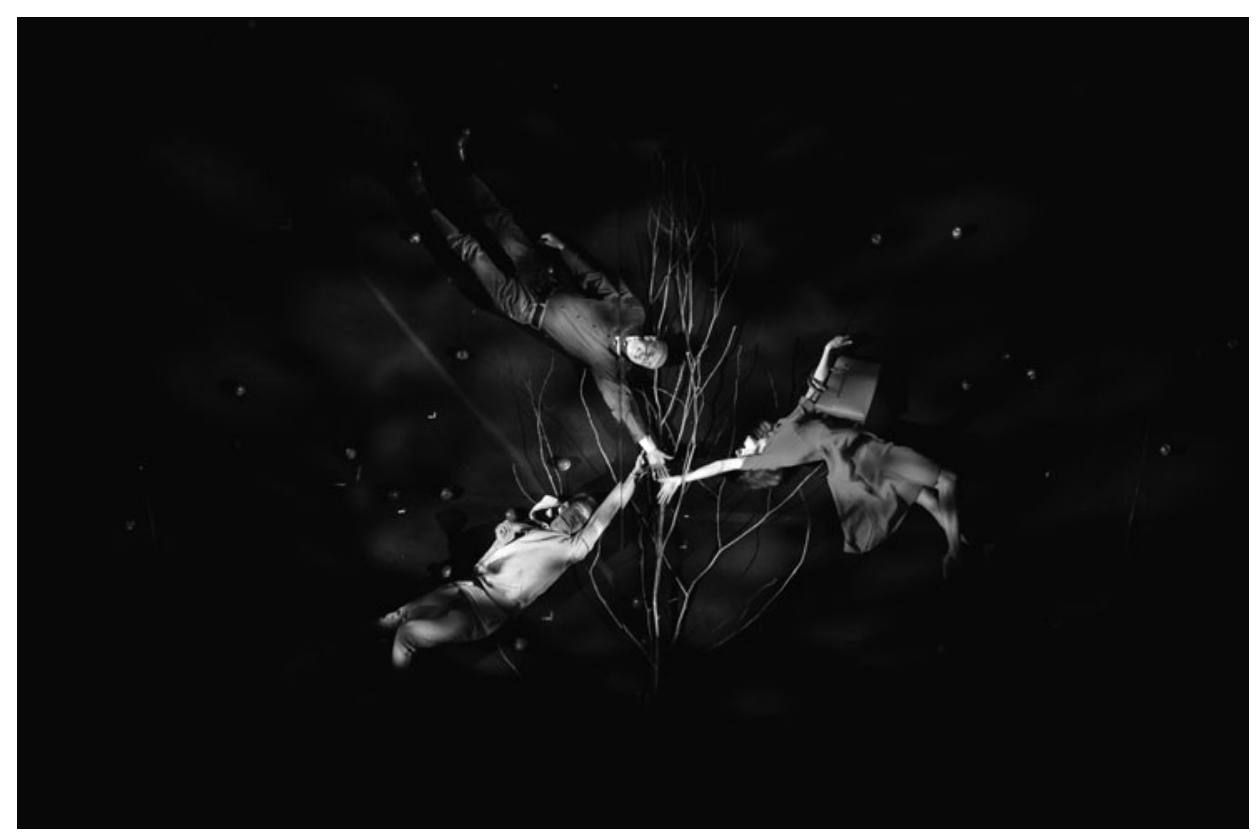

Michail Durnenkov: Utópia. Teatr Nacij, Moskva, premiéra 20. 6. 2018. Réžia Marat Gacalov. Foto tlačové oddelenie festivalu Zlatá maska 2019. Snímka Maria Zajvyjová.

bodit', tak ako sa nemôžu postavy vyslobodit’ z časovej slučky minulosti a budúcnosti, v ktorej uviazli.

So strachom o vlastnú budúcnost’ zápasí na javisku čoraz mladšia generácia. V dramatizácii nórskeho románu Ketila Bjørnstada Pianisty (Pianisti) ${ }^{5}$ sa v roku 1968 pripravuje skupina mládeže na klavírnu sútaž. Vítazstvo im má zabezpečit vysnívanú budúcnost’ hudobníkov. Na ceste za štastím však postavy ovplyvňuje tarcha minulosti. Hlavný mužský predstavitel' Axel Vinding, ktorý pre sútaž opúšṫa školu, sa usiluje vyrovnat's tragickou smrtou svojej matky, ktorá rovnako ako on milovala Debussyho skladby. Ako malý chlapec nedokázal zabránit jej utopeniu sa, ktoré videl na vlastné oči. Jeho konkurentka, vynikajúca klaviristka Aňa Skuug, do ktorej je zamilovaný a ktorá ho napokon porazí v sútaži, zase čelí nešt’astnej minulosti svojich rodičov. Tí sa vzali len preto, že jej matka otehotnela a rozvod odkladajú na čas, ked' Aňa vyrastie. Pochybnosti a dezilúzie prežívajú i d’alšie postavy staršej dospelej generácie, napríklad Axelova osamotená sestra, jeho otec, aj učitel'ka klavíra Selma Ljunge, vydatá za starého chorého muža, pre ktorého sa vzdala kariéry, hoci sa tým finančne zabezpečila. Ich strach o d’alšiu budúcnost', ktorá nebude zodpovedat̉ ich snom, podmieňuje nespokojnost’ s prítomnostou. To vytvára vel'ký nátlak na mladšie postavy. Kým ony ešte predsa len majú istú nádej, dospelí sa musia pred ich očami vyrovnávat’ so životom, ktorý nie je a zrejme ani nebude podl’a ich predstáv. Medzi

${ }^{5}$ Novosibisrkij akademičeskij molod’ožnyj teatr Globus (Novosibírske akademické mládežnícke divadlo Glóbus), Novosibirsk. Dramatizácia a réžia Boris Pavlovič, premiéra 12. 10. 2017. Inscenácia získala Zlatú masku 2019 za najlepšiu činohernú inscenáciu malej formy. 


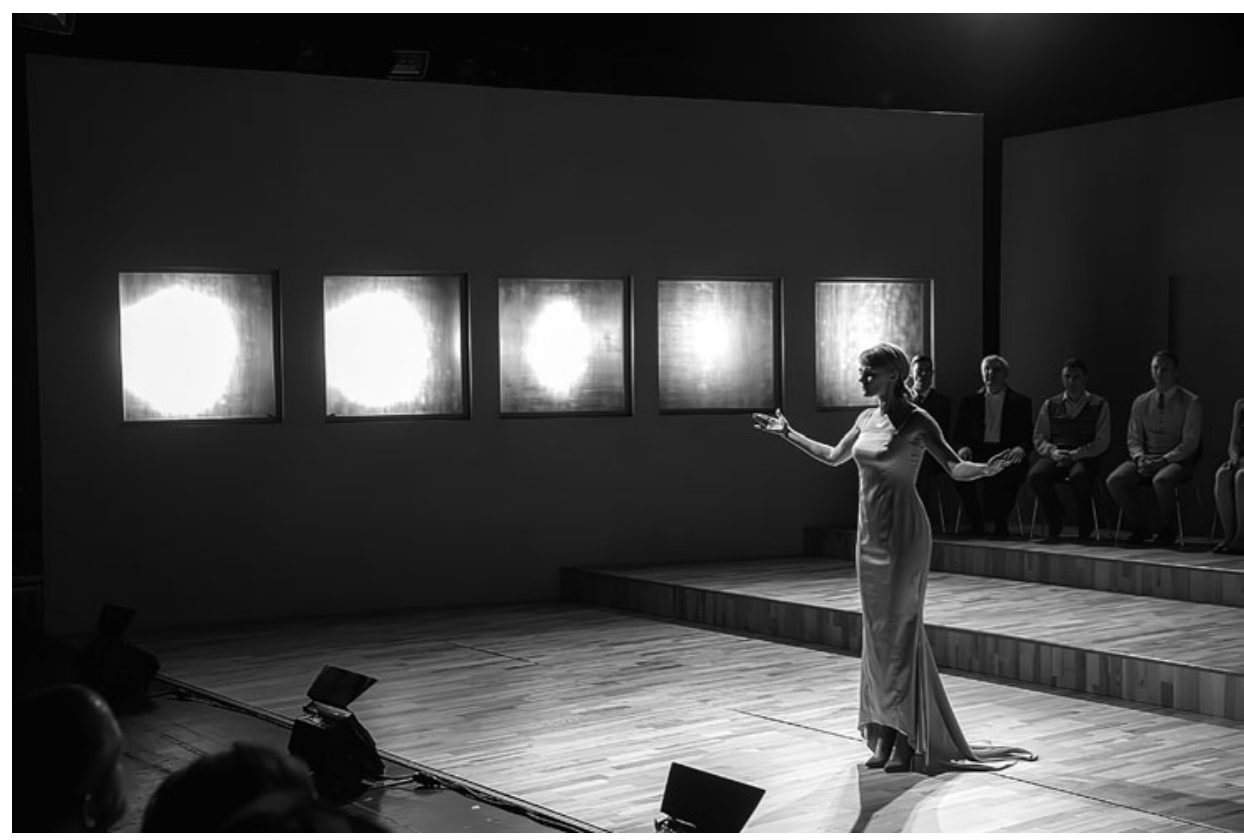

Ketil Bjørnstad/Boris Pavlovič: Pianisti. Novosibisrkij akademičeskij molod’ožnyj teatr Globus, Novosibirsk, premiéra 12. 10. 2017. Réžia Boris Pavlovič. Foto tlačové oddelenie festivalu Zlatá maska 2019. Snímka Viktor Dmitrijev.

generáciami i medzi rovesníkmi sa tak odohráva typická severská dráma rozdrásaného l’udského jedinca, ktorý nemôže prejavit’ navonok, čo cíti.

Chlad vzţahov umocňuje aj scénografia (Ol’ga Pavlovičová). Čisté javisko s plávajúcou podlahou obklopujú len tri sivé steny. Štvrtou stenou sú stoličky rozostavané na konci podlahy tesne pri hladisku. Vytvárajú väzenie, v ktorom sa postavy navzájom strážia a pozorujú, a zároveň väzenie, do ktorého sa samy uzavreli. Skutočne žijú len vo vnútornom svete hudby, kde hrajú impresionistické skladby plné emócií. Nevydarená kariéra znamená koniec existencie. Aby bola prázdnota ich vonkajšieho života bez hudby citel'ná aj navonok, pianisti nemôžu svoje hranie zdiel'at' ani medzi sebou, ani s divákmi: skladatel' Roman Stol'ar skomponoval pre inscenáciu hudbu, v ktorej nezaznie jediný tón klavíra, rovnako režisér neumiestnil na javisku jediné piano.

Protiváhou uzatvoreného chladného sveta sa stáva postava Rebekky, ktorá sa pred debutovým koncertom cestou ku klavíru potkne a spadne. Tento pád jej ukáže inú perspektívu života. Vzdáva sa hudobnej kariéry - ako Alica v Krajine zázrakov po páde do králičej nory pochopila, že môže žit’ aj inak a pritom byt štastná. Jej cestu neskôr nasleduje aj Axel, ked' uprednostní svoju lásku k Ani pred pokračovaním v sútažení s ňou. Prizná, že je lepšia a svoj úspech si zaslúži. Nikto o nej nepochybuje - okrem nej samej. Aj preto sa tiež rozhodne pre „pád“ - na rozdiel od Rebekky však dobrovolný. Uprostred oblúbenej pasáže Axelovej mamy zastaví svoje vystúpenie s orchestrom a odmietne pokračovat'. Anin pokus zmenit’ svoju budúcnost' doženie 
k samovražde jej otca. Hudba, ku ktorej ju priviedol a v ktorej ju v podstate uväznil, bola totiž ich jediným spoločným priestorom, kde si rozumeli.

Sny o budúcnosti, ktoré bránia človeku naplno prežívat’ súčasnost’ a byt’ samým sebou, sú aj témou imerzívnej inscenácie Zerkalo Karlosa Santosa (Zrkadlo Karlosa Santosa $)^{6}$. Počas nej majú diváci možnost’ zažit’ očistnú cestu do detstva a naspät do dospelosti, oslobodit sa od nesplnených túžob, ktoré môžu byt’ častokrát zavádzajúce či obmedzujúce. Projekt je situovaný do podkrovných priestorov budovy pri Puškinskom námestí, kde dvadsiati štyria herci prevedú divákov dvanástimi izbami $\mathrm{s}$ celkovou rozlohou $1000 \mathrm{~m}^{2}$. Predstaveniu predchádza krátke sedenie pod vedením psychológa, na ktorom dvanást divákov (maximálny počet na jedno predstavenie) dostane jedinú úlohu - napísat’ na papier svoje sny, nad ktorými budú počas inscenácie rozmýšlat. Súčastou inscenácie je strata identity - všetci si musia obliect' sivé plášte a sivé masky, nesmú rozprávat’ ani sa navzájom kontaktovat'.

Pút' sa začína v útulne zariadenom byte, ktorého príjemnú atmosféru narúša hádajúca sa dvojica, otec a matka. On opustil ju aj ich spoločné dieta pre inú ženu, ale teraz sa chce vrátit. Po nasadení slúchadiel každý divák v priestore osamie a vydáva sa za postavou otca do sveta biznisu, kde sú l’udia len výkonnými strojmi a kde všetkým ide iba o peniaze, moc a sex. Nasleduje väzenie. No ked’ si diváci zložia masku, za sklom namiesto odsúdeného uvidia vlastnú tvár - sú väzňami svojich nesplnených snov. Majú si uvedomit', že smútok za niečím neuskutočneným či neuskutočnitel’ným človeka väzní a blokuje. Herci ako démoni potom takéhoto človeka vedú čiernymi pokrivenými chodbami do márnice. Diváci sa ocitajú na lôžkach, ale v slúchadlách je počut radostný hlas malého dievčatka, ktoré nad telami mŕtvych objavuje svoju slobodu, tešiac sa z červenej lopty. Cesta za svetlom na konci tunela sa končí v školskej triede, kde majú diváci/žiaci možnost’ upravit’ svoj zoznam snov, o ktorých môžu vzápätí rozjímat’ v detských poschodových posteliach s plyšovými zajačikmi. Po krátkom oddychu v čase detstva, kde sa sníva bez trápenia, je potrebné vrátił sa do dospelosti, získat’ spät identitu, vyjst' z anonymnej samoty. Po znovunadobudnutí vlastnej tváre každý divák zodpovie (môže aj odmietnut') pred ostatnými „áno“ alebo „nie“ na otázky o svojom živote a vloží napísané sny do potrubia na stene, ktoré ich odnesie preč. Odovzdáva ich budúcnosti s vierou, že sa splnia, a prestáva sa o ne strachovat.

\section{ÚTOčisKo minulosti}

Na rozdiel od vyššie zmienených inscenácií, ktoré v minulosti hladajú, neraz bolestivým spôsobom, východiská pre prítomnost' či budúcnost' jednotlivca, Zlatá maska 2019 prezentovala aj iné uhly pohl’adu na predchádzajúce obdobia. Jeden z nich by sme mohli nazvat spomienkovým optimizmom. Ukázal, že čast’ tvorcov má tendenciu prechádzat’ od "sebabičovania“ historickými udalost’ami k ich, v kontexte reality dejín miestami dost’ spornej, poetizácii. Prezentujú ju ako prostriedok, ktorý by mal divákom pomôct’ nájst’ a zlepšit ich postoj k minulosti.

$\mathrm{K}$ „výletom“ s nostalgickou atmosférou patrila napríklad melodramatická insce2018.

${ }^{6}$ Nezávislý divadelný projekt, Moskva. Námet Jevgenij Kadomskij, réžia Talgat Batalov, premiéra 16. 2. 


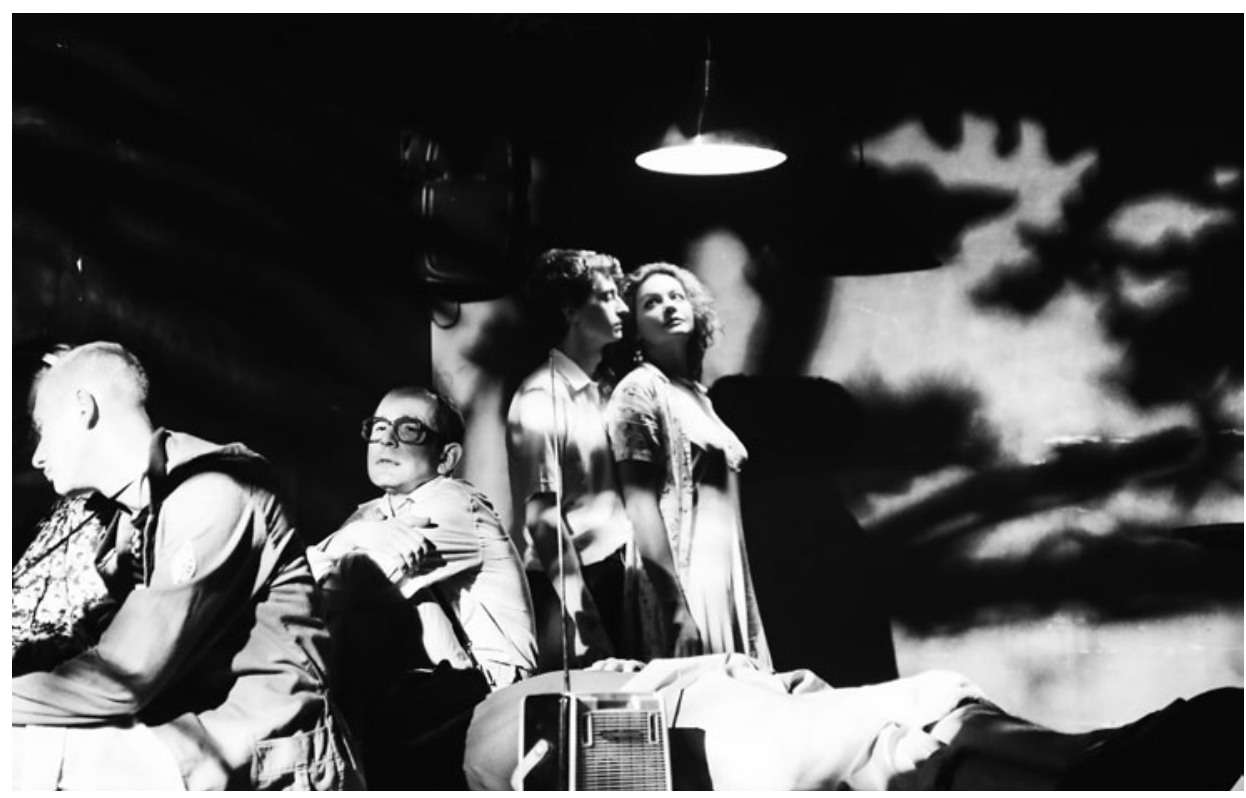

Michail Ugarov: More. Borovice. Centr imeni Vs. Mejerchol’da, Moskva, premiéra 9. 6. 2018. Réžia Saša Denisovová. Foto tlačové oddelenie festivalu Zlatá maska 2019. Snímka Margarita Denisovová.

nácia hry Andreja Kazanceva Staryj dom (Starý dom). ${ }^{7} \mathrm{~V}$ nej „Romeo a Júlia“ z komunálneho bytu prichádzajú do usadlosti, kde kedysi žil Lev Tolstoj, a pri návšteve starého domu sa im vynárajú nežné spomienky. V sprievode piesní Bulata Okudžavu a Charlesa Aznavoura vedú postavy dialóg s minulostou i s históriou zviazanou s dneškom. Režisér Vladimir Pankov prezentuje hru ako výraz vd’aky a lásky k minulosti, aj preto sa pri tejto ceste sebapoznávania postáv cez minulost’ od sovietskych až do dnešných čias nekladie dôraz na historické fakty, ale na emócie. ${ }^{8}$

V niektorých inscenáciách je dôvodom poetizácie minulosti vzṫah ku konkrétnej osobe. Členovia moskovského dokumentárneho divadla Teatr.doc si takýmto spôsobom pripomenuli osobnost' jedného z jeho zakladatel'ov, Michaila Ugarova. ${ }^{9} \mathrm{Na}$ rozdiel od väčšiny inscenácií tohto divadla, ktoré sa dotýkajú súčasnosti, je inscenácia More. Sosny (More. Borovice) ${ }^{10}$ poetickým príbehom zo sklonku autorovej mladosti, vytvoreným na základe Ugarovho nerealizovaného filmového scenáru. Ugarov

\footnotetext{
${ }^{7}$ Centr dramaturgii i režissury (Centrum dramaturgie a réžie), Moskva, réžia Vladimir Pankov, premiéra 5. 9. 2017.

8 ,S tou vd’akou, s akou sa obraciame k pokoleniu našich učitel’ov, sme sa obrátili aj k hre ,Starý dom'. A ved’ vzdávat' vd’aku, to je krása. A kde je krása, tam je aj láska. Tak aj hra Alexeja Nikolajeviča Kazanceva je v prvom rade o láske. O láske, ktorej človek zostane verný do konca." Pozri PANKOV, V. In ABAKŠONOK, N. - CAREVSKAJA, J. (eds.). Zolotaja maska. Rossijskaja nacional'naja teatral'naja premija i festival'. 25 [Bulletin k festivalu], s. 91.

${ }^{9}$ Predstavenie bolo v programe Zlatej masky 1. apríla - v deň prvého výročia smrti Michaila Ugarova. $\mathrm{V}$ tento deň súbor Teatra.doc zároveň uvádzal do života nový priestor na ulici Sadovničeskaja Naberežnaja 69. Oficiálne ho otvorili 12. apríla inscenáciou Budščeje.doc (Budúcnosṫ.doc).

${ }^{10}$ Centr imeni Vs. Mejerchol'da (Centrum Vs. Mejerchol'da), Moskva, réžia Saša Denisovová, premiéra 9. 6. 2018.
} 
v ňom rozpráva príbeh o čašníčke Like a mladom ženatom mužovi, ktorý sa ju počas služobnej cesty rozhodne sprevádzat’ pri jej pokuse o emigráciu, aby ju chránil. Pridávajú sa k skupine emigrantov, ale na hranici s Tureckom sú chytení bezpečnostnými zložkami. Všetkých nakoniec prepustia, okrem Liky. Tá sa so svojím ochrancom náhodne stretne po pätdesiatich rokoch na ulici, jeden druhého však už nespoznajú. Ich príbeh patrí minulosti, ked’ im nad hlavou lietal Sputnik. Nostalgický námet realizovala režisérka Saša Denisovová výsostne divadelnými prostriedkami. Herci sa priznane striedajú v rolách, prezliekajú sa pred očami divákov, rozprávanie o ceste za nenaplnenou nádejou rozjasňujú radostou a hravostou. Inscenácia je tak v konečnom dôsledku nežnou spomienkou na minulé časy i na l’udí, ktorí do nich patrili.

Michailovi Ugarovovi je venovaná aj d’alšia, v tomto prípade experimentálna inscenácia podla novej hry Pavla Priažka DJ Pavel ${ }^{11}$, podávajúca svedectvo o mnohoročnej práci dramatika s týmto divadlom. Pod vedením jedného z najvýznamnejších mladých ruských choreografov Maxima Petrova vznikla „inscenácia-diskotéka“12 o návrate súčasnej mládeže do čias ich rodičov. Kompozíciu z jedenástich piesní pop kultúry osemdesiatych rokov zostavilo a zároveň ju interpretuje osem členov divadla. V oblečení, aké kedysi nosili ich rodičia, tancujú na piesne z nelahkých sovietskych čias, aby vytvorili nový, pozitívnejší vzt’ah k vtedajšej popovej scéne. Bezprostredným, spontánnym tancom chcú vyvolat' chut divákov zatancovat’ si s nimi. A hoci sa na festivalovom predstavení do tejto „oldies diskotéky“ nezapojili všetci diváci, väčšina z nich si hity aspoň s chutou spievala.

Nie všetci tvorcovia ale nasledujú líniu idylizovania histórie. O svojom postoji k nej neraz vypovedajú cez špecifickú dramatickú koncepciu. Tematickým epicentrom retrospektívnej inscenácie 1968. Novyj mir (1968. Nový svet) ${ }^{13}$ sa stal rok 1968, ktorý je v dejinách spojený so študentskými barikádami v Paríži i celej Európe, Pražskou jarou, vraždou Martina Luthera Kinga či vpádom spojeneckých vojsk do Československa. V inscenácii sa o týchto historických medzníkoch ale nehovorí - vypovedá sa o nich mlčaním. Vel'ké dejinné udalosti sú stratené niekde medzi symbolickými šest'desiatimi ôsmimi obrazmi, z ktorých konceptuálny režisér Dmitrij Volkostrelov dovolí divákom uvidiet iba pät', aj to nie v chronologickom poradí. Pät hercov v nehybnom tichom priestore cituje pasáže z rôznych článkov uverejnených v časopisoch Novyj mir (na ktorý odkazuje názov inscenácie), Inostrannaja literatura, Iskusstvo kino a Teatr. Fragmenty textov prezentujú dobové namierenie týchto periodík proti západnej kultúre. Venujú sa banálnym témam a striedajú sa s úryvkami dialógov z polozabudnutých filmov. Čas je opät vnímaný ako točiaci sa v kruhu, nelineárny ako v Durnenkovovej Utópii. Zvyšných šest’desiattri obrazov zostáva skrytých, pretože minulost’ už nie je možné uvidiet’ plynule a súvislo.

O tom, že je dôležité hl'adat' pravdu a nestratit’ sa medzi klamstvami, ktoré boli $\mathrm{v}$ istých časoch l'ud’om ako „pravda“ nanucované, vytvoril režisér Dmitrij Jegorov „činoherný koncert v dvoch častiach“14 s názvom Ja. Drugoj. Takoj. Strany (Ja. Iný.

\footnotetext{
${ }^{11}$ Teatr.post (Divadlo.post), Petrohrad, premiéra 20. 6. 2018.

${ }^{12}$ DJ Pavel. [Anotácia k inscenácii]. [online]. [cit. 21. 4. 2019]. Dostupné na internete: https://teatrpost. timepad.ru/event/978679/.

${ }^{13}$ Muzej sovremennogo iskusstva Garaž (Múzeum súčasného umenia Garáž), Moskva. Réžia Dmitrij Volkostrelov - spolupodielal sa aj na inscenácii DJ Pavel, dátum premiéry z dostupných zdrojov neznámy

${ }^{14}$ Ja. Drugoj. Takoj. Strany. In ABAKŠONOK, N. - CAREVSKAJA, J. (eds.). Zolotaja maska. Rossijskaja nacional'naja teatral'naja premija i festival'. 25. [Bulletin k festivalu], s. 66.
} 


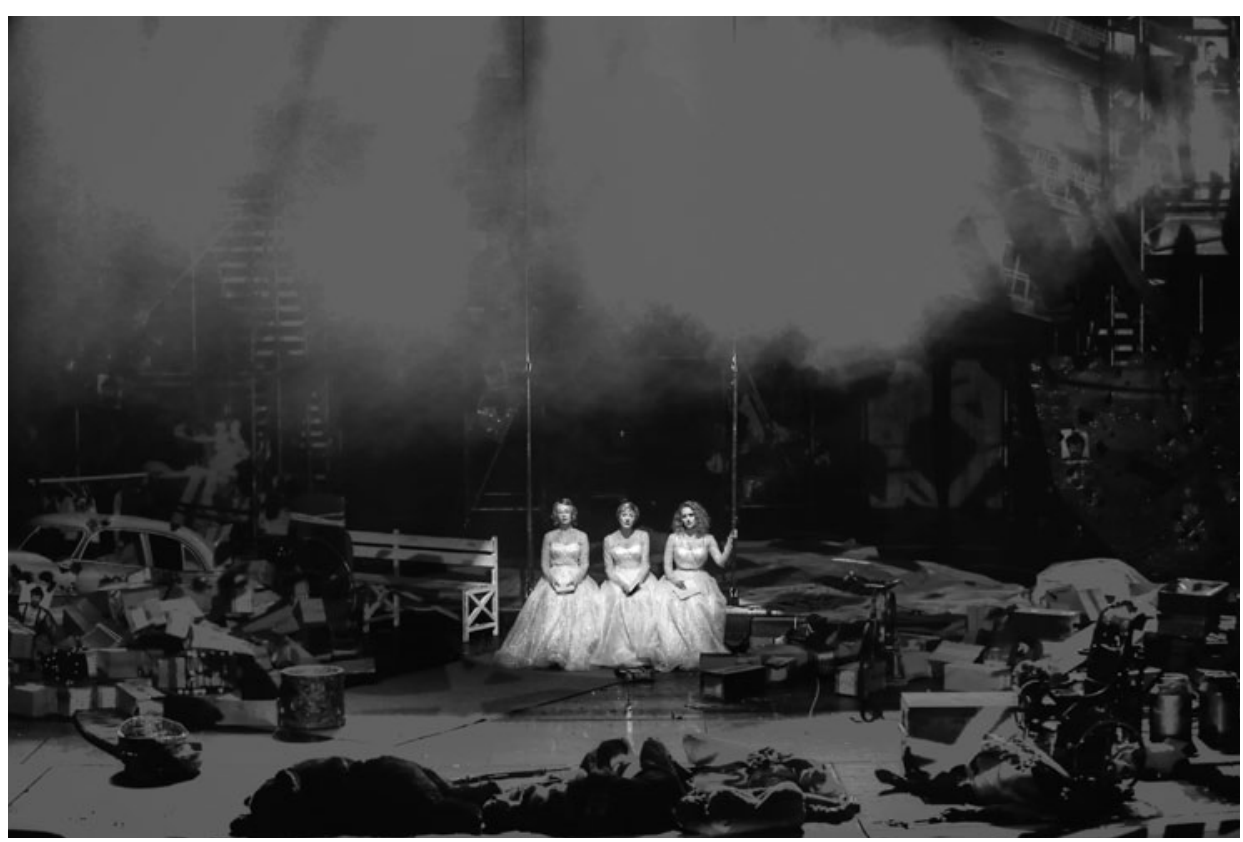

Jurij Oleši/Svetlana Ščagina: Traja tlstí. Čast’ 2. Železné srdce. Bol'šoj dramatičeskij teatr im. G. A. Tovstonogova, Petrohrad, premiéra 31. 3. 2018. Réžia Andrej Mogučij. Foto tlačové oddelenie festivalu Zlatá maska 2019. Snímka Stas Levšin.

Taký. Krajiny) na motívy ruského básnika, výtvarníka a sochára, predstavitel’a moskovského konceptualizmu Dmitrija Prigova.

Ďalším výrazným spôsobom oživovania minulosti je nazeranie naň optikou karikatúry, irónie, ba až výsmechu, s podčiarkovaním historických absurdít a paradoxov. Spolu s poetizáciou minulosti možno oba tieto spôsoby vnímat’ aj ako zrejmú reakciu na zvýšenú mieru démonizácie, s akou túto krajinu a jej históriu dnes vníma a vykresl'uje okolitý svet a snahou zabránit', aby tomuto obrazu ruský človek uveril.

Režisér Andrej Mogučij v prvých dvoch dieloch plánovanej ságy Tri tolst’aka. Epizod 1. Vosstanije - Epizod 2. Železnoje serdce. (Traja tlstí. Čast' 1. Povstanie - Čast' 2. Železné srdce), vybudovanej ako fantazijné akrobatické variácie na motívy románu Jurija Olešiho z roku 1924, vrátil k sovietskym časom revolúcie a vojen, aby oddelil umenie od politiky ${ }^{15}$. Vedec Gaspar Arneri na javisku bojuje s chaosom spôsobeným energiou T-3 („,traja tlstí”), ktorá vznikla počas tajného experimentu. Na Zem prenikla z inej dimenzie po priblížení Saturnu s Jupiterom a v jej dôsledku sa dejú nielen prírodné, ale predovšetkým spoločenské katastrofy - revolúcie, vojny. Spolu s revolucionármi z cirkusu, chodcom po lane Tibulom a gymnastkou Suok, sa Arneri usiluje vzkriesit lưdskú civilizáciu a zneutralizovat’ energiu T-3. Režisér buduje svoju

${ }^{15}$ Bol’šoj dramatičeskij teatr im. G. A. Tovstonogova (Vel'ké dramatické divadlo G. A. Tovstonogova), Petrohrad. Traja tlstí. Čast’ 1. Povstanie, premiéra 26. 1. 2018, Čast’ 2. Železné srdce, premiéra 31. 3. 2018. Inscenácia získala Zlatú masku 2019 za najlepšie kostýmy v činohernom divadle (Alexander Šiškin). 


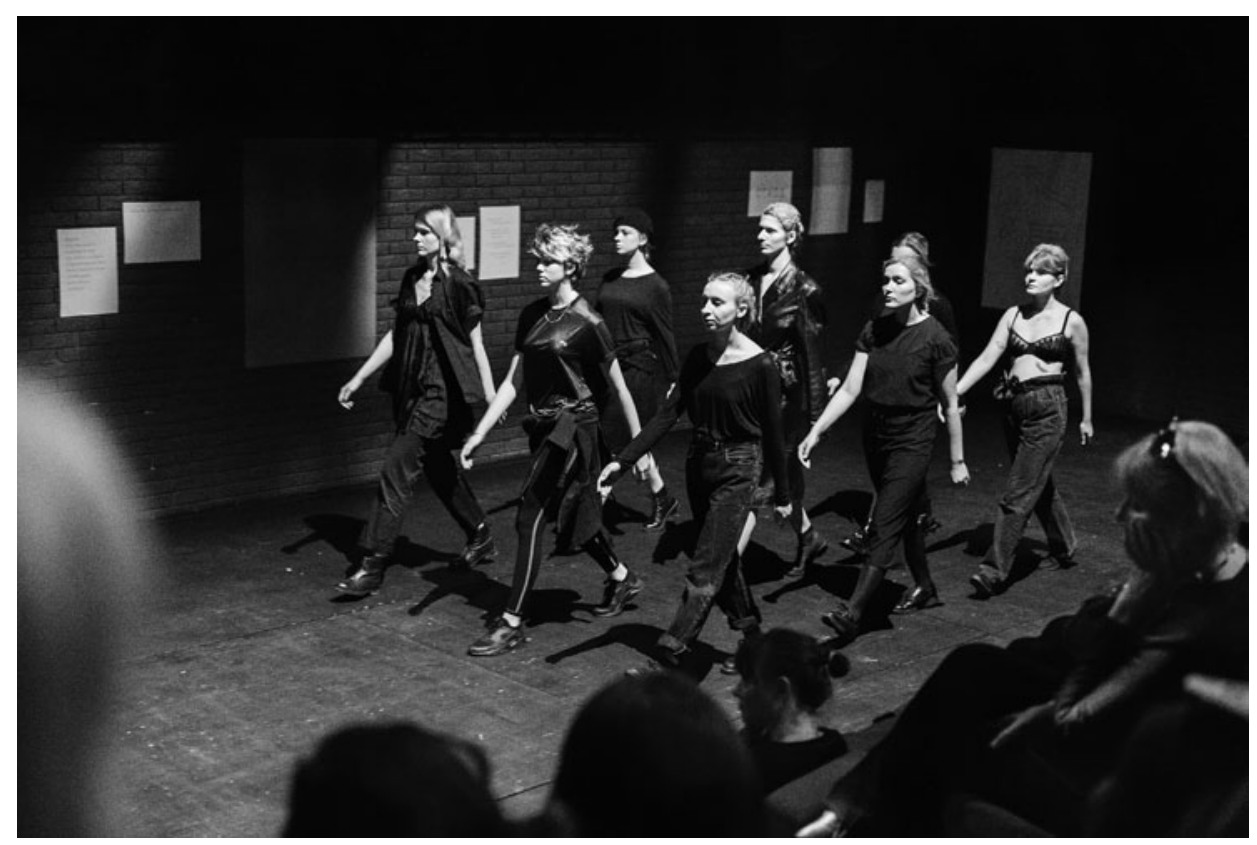

Andrej Stadnikov: Vlast'. Centr imeni Vs. Mejerchol'da, Moskva, premiéra 11. a 12. 11. 2017. Réžia Andrej Stadnikov. Foto tlačové oddelenie festivalu Zlatá maska 2019. Snímka Jekaterina Krajevová.

„rozprávku-antiutópiu, ktorá bude zaujímavá pre mládež aj dospelých“16 na princípe Ejzenštejnovej montáže atrakcií, kde má každý obraz čo najsilnejšie zasiahnut’ emocionálnu stránku diváka. Vzniká poetický, metaforický cirkus plný pestrofarebných štylizácií histórie a národných symbolov, pri ktorom publikum zatajuje dych, ako napríklad pri chôdzi herca po lane ponad hl'adisko až ku galérii.

V súvislosti s návratom do sovietskych čias je potrebné sa zmienit’ o takmer štvorhodinovom experimente Rodina (Vlast') ${ }^{17}$. Dve časti vel'koformátovej inscenácie zobrazujú storočnú históriu ruského národa z dvoch časových perspektív - ako spomienku a súčasne ako jej oživenie. Podl’a tvorcov ide o príbeh „rovnako o začiatku sovietskej epochy, ako aj o čase, ktorý prišiel potom - čase, ked' sme sa túlali pomedzi artefakty minulosti, ale žili v inej skutočnosti. ,My` to sú tí, ktorí sa narodili v ZSSR, ale vyrástli v Rusku. “18

Prvá čast’ referuje o sovietskej ére z pozície prítomnosti. Zaznievajú autentické materiály a záznamy o nedávnych problémoch Ruského futbalového zväzu, ktoré spôsobila snaha pričlenit’ k Rusku futbal Krymu, ale napríklad aj repliky z fragmentu

${ }^{16}$ Tri tolst'aka. [Anotácia k inscenácii]. [online]. [cit. 11. 4. 2019]. Dostupné na internete: https://bdt.spb. ru/спектакли/три-тодстяка/.

${ }^{17}$ Centr imeni Vs. Mejerchol'da (Centrum Vs. Mejerchol'da), Moskva. Inscenácia v réžii autora námetu Andreja Stadnikova získala Zlatú masku 2018 ako špeciálnu cenu poroty za „Experiment, ktorý sa stal objavom", premiéra 11. a 12. 11. 2017.

${ }^{18}$ Rodina. [Anotácia k inscenácii]. [online]. [cit. 17. 4. 2019]. Dostupné na internete: http://meyerhold.ru/ rodina/. 
scenára kultového sci-fi filmu Matrix. Realita je relatívna, signalizujú tvorcovia. Čo ked' i my žijeme v matrixe, a nevieme o tom? Čo ked' sa vo virtuálnej realite odohrávala aj sovietska éra? Jej obraz na javisku vzniká ako predstava teenagera čítajúceho knihy z oných čias, ktoré našiel v knižnici starej mamy. Ich fragmenty ožívajú vo svete okolo neho. V jeho predstavách sa pritom rodí obraz „impozantnej sily“"19, ktorú stelesňuje armáda blondínok ako vizuálneho i významového symbolu Ruska, jeho sily. Vyše pätdesiat blondínok v čiernom oblečení vytvára v priestore počas inscenácie rôzne figurálne kompozície okolo pyramídy umiestnenej v strede sály. Pyramída je hladiskom a na jej vrchu sa za chrbtami divákov nachádza malé javisko, z ktorého vychádza vel'ký zapletený vrkoč blond vlasov, akcentujúci poetiku inscenácie. Bulletin upozorňuje na to, že každá z účastníčok je nielen zástupkyňou vlastnej strany, ale má možnost’ ovplyvnit štruktúru a časovú formu celej kompozície. ${ }^{20}$ Na stenách z nimi visia autentické citácie myšlienok a reakcií všetkých účastníkov projektu, napr. "Je to peklo" - „Sme súčasníci“ - „Služba múzam nestrpí márnivosti“ - „Príliš málo slobody, zle je - príliš vel'a slobody, ešte horšie“ - „Ak by som mohla zmenit’ minulost', tak by som ju zmenila" (a i.).

Druhá čast', ktorej základom je hra Smrt’ Lenina (orig. Lenins Tod, 1970) od nemeckého dramatika Volkera Brauna, sa zbavuje fantazijného idealizovania minulosti a priam dokumentárne sa snaží zobrazit hrôzu vnútorného zápasu niekdajších predstavitel’ov Komunistickej strany Sovietskeho zväzu. Na javisku ožívajú postavy vedúcich revolucionárov a politikov, strojcov masových vrážd a bol’ševických represií - Karl Berngardovič (pseudonym Radek), Nikolaj Bucharin, Grigorij Zinoviev, Viačeslav Molotov, Michail Tomskij, Felix Dzeržinskij (prezývaný Železný Felix), Serg Ordžonikidze a Viačeslav Menžinskij. Armáda blondínok z prvej časti sa tak mení na jednotlivcov - všetkých politikov, ktorí sa pred storočím usilovali vybudovat’ novú podobu ruskej krajiny, totiž opät stvárňujú svetlovlasé herečky. Väčšina ich výstupov sa odohráva na pyramíde pri vrkoči. Aby ich diváci videli, musia sa za nimi otočit'. Ak tak neurobia, počujú hlasy minulosti a pred sebou vidia d’alšie mladé svetlovlasé dievčatá zo súčasnosti, ktoré sa pozerajú na Olymp a zároveň Golgotu ruských dejín. Túto „hru“ o krajinu pozoruje z balkóna z tieňa nevychádzajúci Stalin, čo odkazuje na jeho povestný strach z naplnenia veštby, podla ktorej nemal nikomu dovolit' pozriet' sa mu do očí, aby ho neuriekol. V tomto prípade ho však, rovnako ako Trockého, hrá mužský interpret.

Pripomenutie si minulosti pre pamätníkov i mladú generáciu formou rekonštrukcie je tu teda predstavené ako spôsob očisty, ako nutnost’ pripomínat si históriu v záujme vyvarovania sa podobných chýb pri novej profilácii krajiny. Zároveň bol citel’ný odkaz na súčasnost', ked’ sa na politickej scéne objavuje čoraz viac žien.

\section{Výmena rol - nový pohl’ad na klasiku}

Snahy inscenátorov o zosúčasnenie klasických diel sa už dávno netýkajú len výtvarnej zložky, ale čoraz častejšie aj originálnej interpretácie samotného textu. Výrazné režisérske osobnosti ruského javiska sa usilujú demýtizovat’ a konfrontovat zakorenené mýty klasických diel a posunút ich do nových rovín. Vlastnými originálnymi

\footnotetext{
${ }^{19}$ Tamže.

${ }^{20}$ Rodina. [Bulletin k inscenácii]. Moskva : Centr imeni Vs. Mejerchol’da, 2017. Nestránkované.
} 


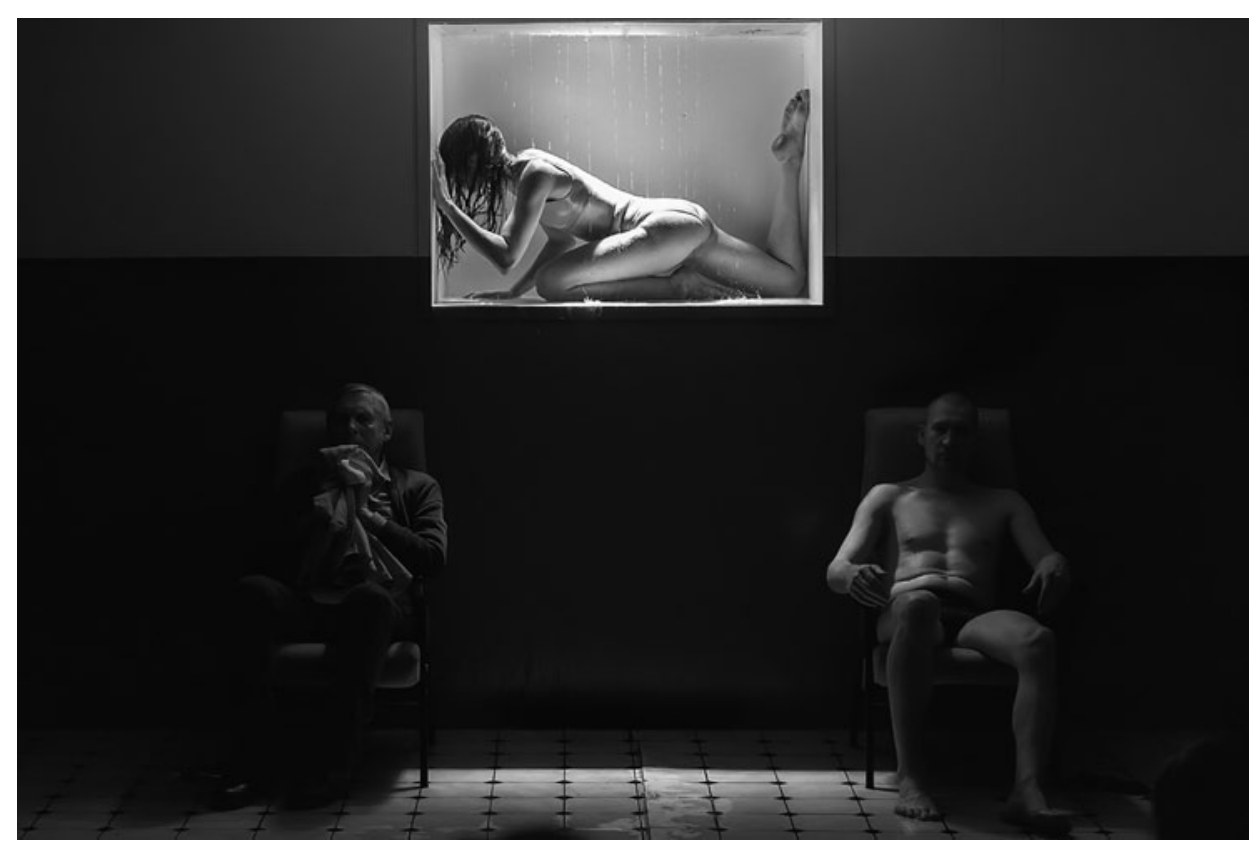

Andrej Platonov: Rieka Potudaň. Teatr dramy im. A. S. Puškina, Pskov, premiéra 23. 3. 2018. Réžia Sergej Čechov. Foto tlačové oddelenie festivalu Zlatá maska 2019. Snímka Dmitrij Dubinskij.

videniami známych príbehov a režijnými nadstavbami rozkrývajú nové možnosti, ako ich aplikovat’ čo najviac na mieru súčasnosti, vytrhnút divákov zo stereotypov, ktoré s nimi majú spojené, a predstavit’ ich v celkom inom svetle a súvislostiach. Túto líniu väčšinou rozvíjajú smerom od jedinca k spoločnosti.

Na festivale Zlatá maska 2019 boli za novátorský prístup ku klasickým dielam ocenené inscenácie hry Alexandra Puškina Malé tragédie $e^{21}$ a Reka Potudaň (Rieka Potudaň) na motívy rovnomenného diela Andreja Platnova22. Tak ako sa v Rieke Potudaň premenili postavy platonovovoského mýtu na oživené archetypy Hrdinu, Život a Smrt', pričom hranicu medzi živými a mŕtvymi zastúpila okolo tečúca rieka Potudaň ako postava Absolútna, tak aj súčasný pohl'ad na klasiku predstavuje predovšetkým prekonávanie hraníc, vd’aka čomu sa dané dielo prinavracia do sveta živých. Jedným z najvýraznejších prvkov reinterpretácií klasiky v mene jej zosúčasnenia sa v ruskom divadle už niekol'ko rokov ukazuje byt’ obsadzovanie žien do mužských rol.

${ }^{21}$ Gogol'-centr (Gogol'_centrum), Moskva, réžia Kirill Serebrennikov, premiéra 17. 9. 2017. Zlatá maska 2019 za najlepšiu réžiu. Serebrennikov získal Zlatú masku 2019 aj za najlepšiu baletnú inscenáciu, za dielo Iliu Demuckého Nurejev o baletnom majstrovi Rudol'fovi Nurejevovi, uvádzanú v moskovskom Bol’šom teatre. Obe inscenácie režíroval z domáceho väzenia, v ktorom sa nachádzal od konca mája 2017 do apríla 2019 pre obvinenie zo spreneverenia finančných prostriedkov. Na slávnostnom ceremoniáli odovzdávania cien Zlatej masky 2019, ktorý sa konal 16. apríla, sa už zúčastnil osobne.

${ }^{22}$ Teatr dramy im. A. S. Puškina (Divadlo drámy A. S. Puškina), Pskov, réžia Sergej Čechov, premiéra 23. 3. 2018 . 


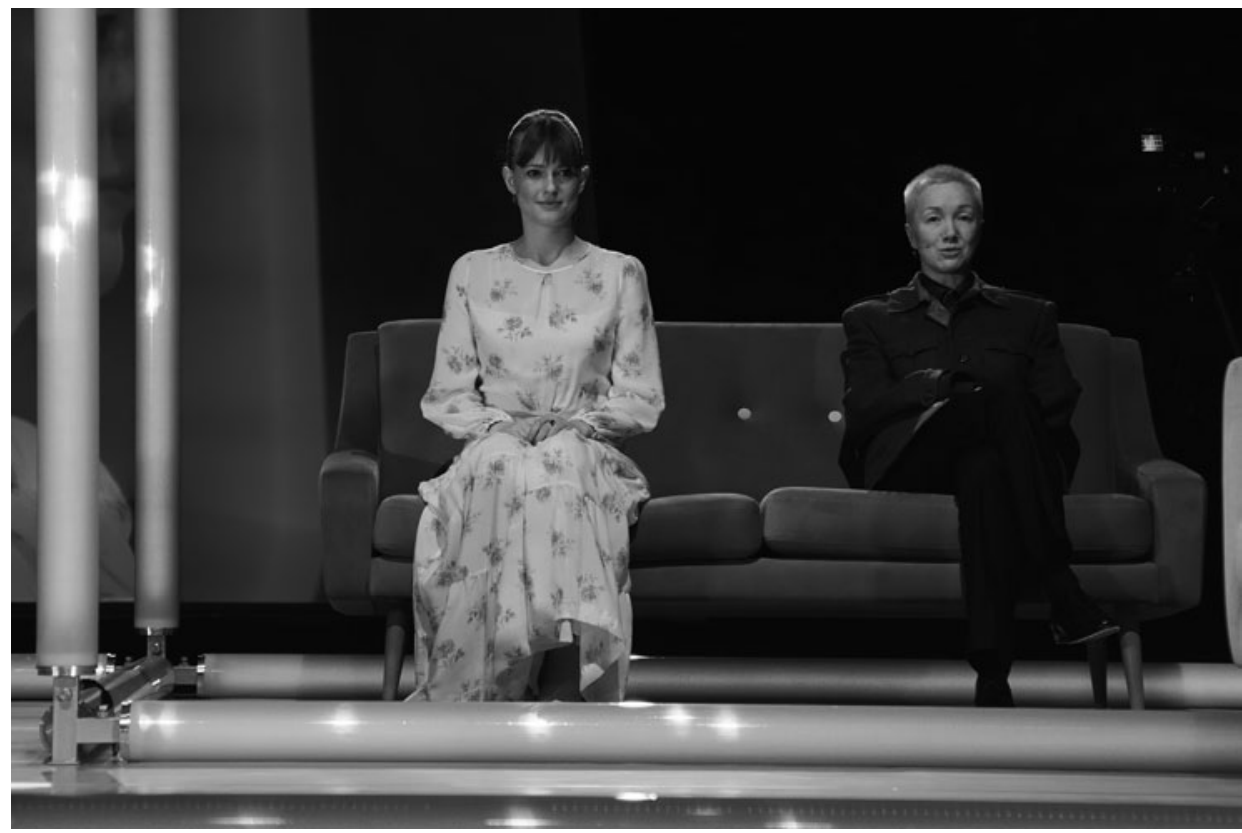

Anton Čechov: Tri sestry. MXT im. A. P. Čechova, Moskva, premiéra 30. 5. 2018. Réžia Konstantin Bogomolov. Foto tlačové oddelenie festivalu Zlatá maska 2019. Snímka Jekaterina Cvetkovová.

Týmto prístupom je povestný aj režisér Konstantin Bogomolov. V inscenácii Čechovových Troch sestier ${ }^{23}$ obsadil herečku Dariju Morozovú do roly baróna Tuzenbacha. ${ }^{24}$ Morozovej barón Tuzenbach vystupuje v inscenácií ako jediný človek, ktorý nie je unavený životom, naopak, miluje ho. A vie milovat tak, ako vie milovat iba žena. Navonok síce herečka zostáva rovnako sošná a jej intonácia je rovnako bez akcentov ako u ostatných postáv, ale vášeň jej vidno v očiach, ktorých obraz sa premieta na vel'ké obrazovky obklopujúce holú svietiacu konštrukciu domu. Napriek láske k životu Tuzenbacha hubí okolie, takže jeho odchod na duel sa môže javit’ aj ako úmyselná samovražda. V hre medzi ostatnými mužmi a ženami nemá miesto, podl'a divadelnej kritičky Ol'gy Fuxovú je totiž „,človekom-androgynom“ - mytologickou postavou obojpohlavnou bytostou plnou sily, ktorá sa vzbúrila proti bohom, za čo bola Diom roztatá na dve polovice, ktoré sa teraz hl'adajú, aby sa opät’ spojili. No Tuzenbach márne hladá svoju polovicu.

Bogomolovovým ciel'om bolo podla jeho vlastných slov urobit Čechovov text „,nesmierne živým, nesmierne súčasným, nesmierne skutočným“. Zbavil sa akéhokol’vek symbolizmu Troch sestier, aby sa odhalila „najpodrobnejšia, najtenšia, absolútne vystavaná psychologická štruktúra“. ${ }^{25}$ Tentokrát hru nedoplńal o vlastné režijné obrazy.

\footnotetext{
${ }^{23}$ MXT im. A. P. Čechova (MCHT A. P. Čechova), Moskva, premiéra 30. 3. 2018.

${ }^{24}$ Darija Moroz bola za stvárnenie tejto postavy ocenená Zlatou maskou 2019 pre najlepšiu herečku.

${ }^{25}$ BOGOMOLOV, K. In ABAKŠONOK, N. - CAREVSKAJA, J. (eds.). Zolotaja maska. Rossijskaja nacionalnaja teatral'naja premija i festival'. 25. [Bulletin $\mathrm{k}$ festivalu], s 63.
} 


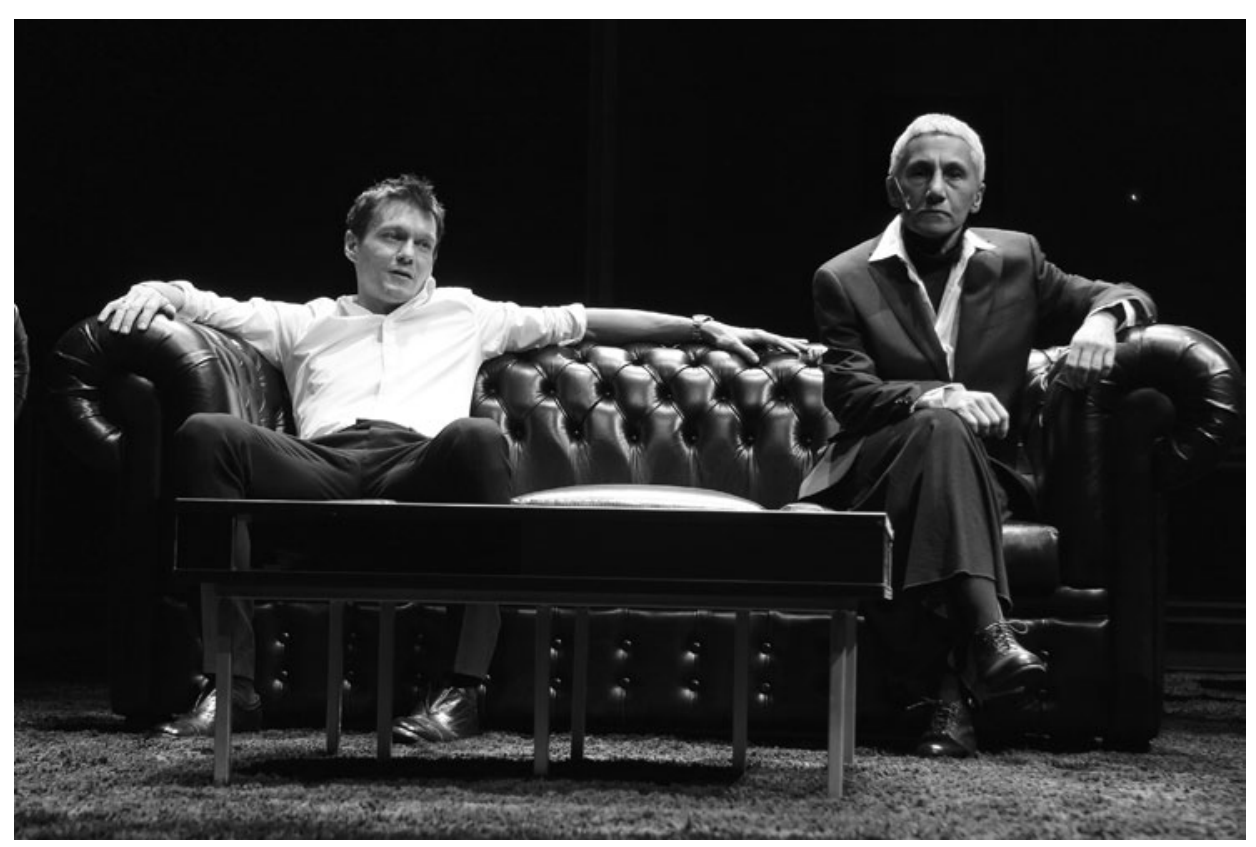

Fiodor Dostojevskij: Karamazovovci. MXT im. A. P. Čechova, Moskva, premiéra 26. 11. 2013. Réžia Konstantin Bogomolov. Foto tlačové oddelenie festivalu Zlatá maska 2019. Snímka Jekaterina Cvetkovová.

Nechal hercov interpretovat’ repliky do mikrofónov bez dôrazov, pološeptom, priam hypnoticky, aby sa diváci mohli bez rozptyl’ovania ponorił do ich híbky. Rovnako pohyb hercov je minimalistický, väčšinou sú usadení na divánoch, ako obraz inteligencie teoretizujúcej o živote, ktorý nežije. Len málokedy je táto statika narušená, napríklad pri šansóne Tuzenbacha sediaceho za klavírom a s cigaretou v ústach spievajúceho pieseň Davajte vypijom, Nataša (Vypime si, Nataša). Jedným z hlavných protagonistov inscenácie je konštrukcia svietiaca rôznymi farbami (scénografia Larisa Lomakinovová). Postavy sú ukryté v jej vnútri, no chýbajú tu steny: ako v reality show sú kamerami neustále pozorované a premietané na obrazovky. Ich dom im už nepatrí - režisér pracuje s Čechovovým motívom straty domu, no nie v zmysle majetku, ale ako so symbolom l'udskej identity, miesta a zmyslu života.

Režijný rukopis inscenácie Troch sestier nadväzuje aj na Bogomolovu úspešnú staršiu inscenáciu dramatizácie románu Fiodora Dostojevského Karamazovy (Karamazovovci) s podnadpisom - Fantazii režissiora K. Bogomolova na temu romana F. Dostojevskogo (Fantázie režiséra K. Bogomolova na tému románu F. Dostojevského) ${ }^{26}$, na ktorej rovnako spolupracoval so scénografkou Larisou Lomakinovovou. Dej na javisku aj tu situovali do súčasného sveta, tentokrát mocných oligarchov, rovnako vysedávajúcich na drahých divánoch a kreslách a s radostou exhibujúcich pred kamerou - Bogomolovov motív zvrátenej podstaty reality show. Svoju dvornú herečku

${ }^{26}$ MXT im. A. P. Čechova (MXT A. P. Čechova), Moskva, premiéra 26. 11. 2013. Inscenácia bola zaradená do výberu špeciálnej programovej sekcie festivalu Zlatá maska - Russian Case 2019. 


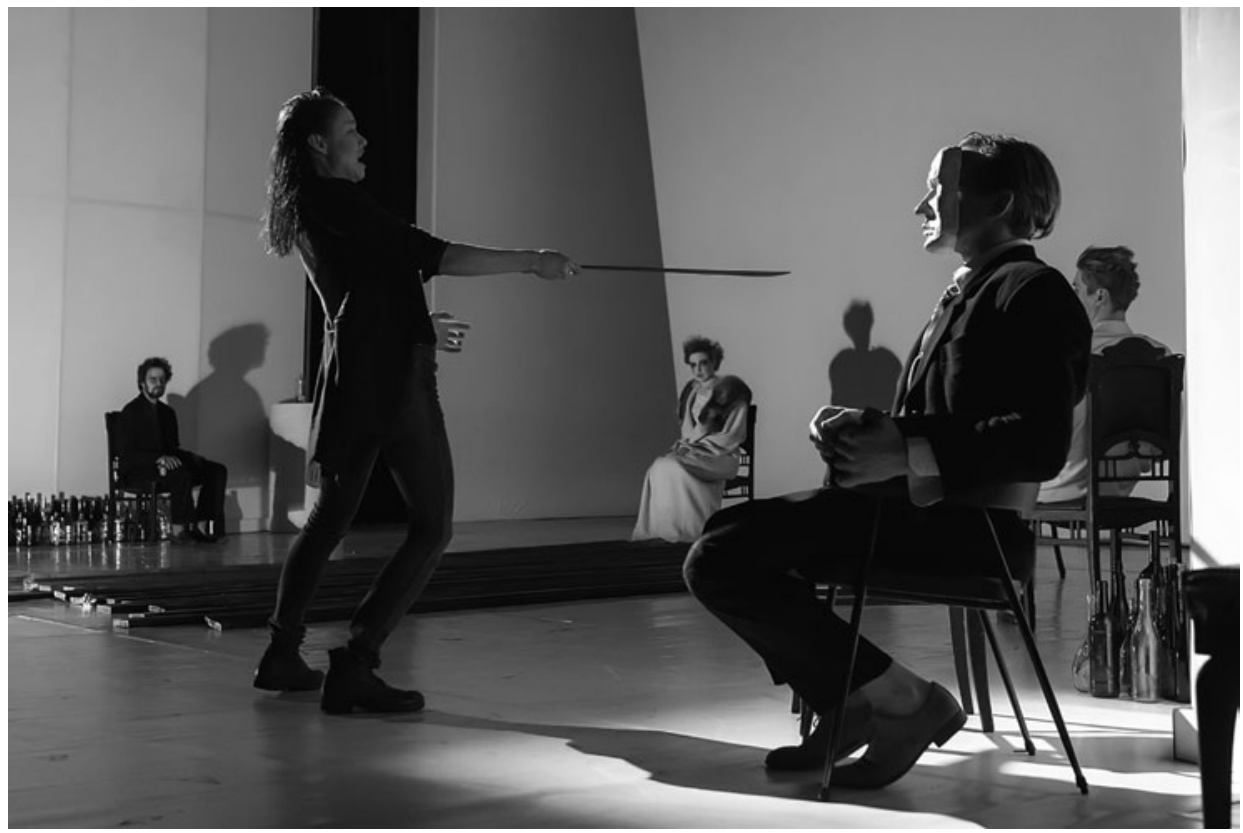

William Shakespeare: Hamlet. Teatr im. Lensoveta, Petrohrad, premiéra 22. 12. 2017. Réžia Jurij Butusov. Foto tlačové oddelenie festivalu Zlatá maska 2019. Snímka Dmitrij Dubinskij.

Rozu Chajrullinovovú tu obsadil do mužskej roly kňaza Alexeja Karamazova. Táto útla žena s mužskými črtami, no zároveň éterického, miestami až detského vzhl'adu, dodala role krehkost’ a jemnost', umocňujúc ich tenkým, zachrípnutým hlasom, pripomínajúcim starého chorého človeka. Jej postava Alexeja akoby nemala vek ani pohlavie - stala sa archetypom viery v Boha, ktorú nikto nepotrebuje, strateným l'udským svedomím, túlajúcim sa medzi skazenými postavami. Uprostred hyenistickej spoločnosti sa javí byt๋ odsúdenou na zánik. Nadväzuje ale vzt̉ah s ochrnutou Lízou, ktorá dostala od režiséra charakteristiku „kus dreva“ a skutočne má namiesto končatín len dlhé tenké drevené palice. Ich spojenie pôsobí bolestne, ako obraz krutej reality života, v ktorej sa slabý môže opriet len o slabého, pretože "silným“ je ukradnutý. Cestu k vykúpeniu zo svojej slabosti nachádzajú v samovražde, ked’ hned” po svadobnom obrade skočia zo strechy vysokej budovy. Toto ich "svadobné video" ukazuje režisér na vel'kých obrazovkách. Viera i nádej prestali existovat', súčasnému svetu u Bogomolova vládnu moc a hriech.

Odvážnym prístupom ku klasickým textom je známy aj režisér Jurij Butusov. Jednu z najväčších tragédií dramatickej literatúry, Shakespearovho Hamleta ${ }^{27}$, poňal ako štvorhodinovú čierno-bielu kompozíciu so štylizáciami, divadlom na divadle, pantomímou i krvavo-červenými výjavmi orgiastických tancov postáv pod vplyvom drog a alkoholu. Asketicky zariadené javisko obklopil vel'kými, sterilne bielymi stenami a šikmým plafónom evokujúcim plátno. Premietat’ sa na ňom ale nebude, zostane

${ }^{27}$ Teatr im. Lensoveta (Divadlo Lensoveta), Petrohrad, premiéra 22. 12. 2017. 
nepoškvrnené ako režisérova predstava o dánskom princovi. Scénu len občas pretína mólo dlhého čierneho stola, ktorý sa miestami zaplní fl'ašami. Dej sa môže odohrávat' všade a nikde, možno ho vidíme a možno si ho len predstavujeme - podla toho, akí sme, podla nášho svedomia. Aj herci sa vnárajú do svedomí rôznych postáv, pri striedaní sa v jednotlivých rolách neberú ohl’ad na ich pohlavie. Hamleta hrá vo viacerých obrazoch žena, Oféliu zase muž s líčením míma, presne v duchu repliky „Pánboh vám dal jednu tvár, a vy si robíte druhú “28. Nakol'ko však bola Ofélia v tomto dialógu s Hamletom „mímom“, pred očami divákov ju dabovala vedla stojaca herečka.

Laura Licchelauriová, hrajúca Hamleta v neutrálnom, no predsa len viac maskulínne ladenom oblečení (nohavice, sako, vojenské kanady), ho interpretovala ako človeka pevne uvedomelého, racionálneho, rozhodnutého, no zároveň plného emócií. Jej drobná štíhla postava a jemné ázijské črty mu dodali nežný nádych. Obsadením ženy do mužskej roly ale Butusov nemal v úmysle dotknút' sa otázok rodovej rovnosti či ženskej emancipácie. Striedaním sa viacerých hercov rôznych pohlaví v postave Hamleta vyjadril, ako ho sám vníma: „Hamlet je už dávno mýtus, nie človek. Je to duchovná substancia, nemajúca ani vek, ani pohlavie, ani váhu, ani vôňu. Jeden z hlavných hrdinov svetovej kultúry, večný myslitel', večná obet', Hamlet navždy zostane tajomstvom. On je ten, ktorý dáva výzvu dobe. Pochopit Hamleta - znamená pochopit’ dobu. (...) V inscenácii je Hamlet rázny, nezmieritel’ný a nemilosrdný k ohavnosti - ako diet’a. A rovnako ako diet’a je krehký a čistý. V tom je jeho neporazitelná sila. On inšpiruje lásku. “29 Táto Butusovova definícia Hamleta, ktorú doňho podl’a neho vložil sám Shakespeare, sa stala témou a obsahom inscenácie. Všetci na javisku i v hl'adisku sa mali stat' Hamletom, aby ho dokázali pochopit'.

\section{(Anti)hrdinovia dneška - Ruská trojka}

Predlohy klasických dramatických alebo prozaických textov na ruských javiskách nesprevádzajú vždy len vážne a tragické emócie. Režiséri často rozohrávajú ich serióznu výpoved’ cez komické výrazové prostriedky. Neraz pritom pracujú s národnými symbolmi, tradíciami či typickými povahovými črtami ruského človeka.

Tak režisér Oleg Lipoveckij premenil Mŕtve duše ${ }^{30}$ na pestrofarebnú klauniádu, kde celý príbeh zahrajú traja herci. Pri odpise majetku či akejsi inventúre v second hande nachádzajú traja predavači paperbackovú verziu Gogolovho románu. Začítajú sa doň a zrazu sa prenesú do jeho deja - začína sa road movie ruskej trojky po rodnej krajine v symbolickej dĺžke tri hodiny. Počas nej zbiera Čičikov mŕtve duše, ktoré predstavuje staré oblečenie zo second handu. Režisér do dramatizácie doplnil postavy troch hovoriacich koní - súputníkov Čičikova, ktorí s ním cestujú po krajine a bezprostredne reflektujú (t. j. napodobňujú a parodujú) to, čo vidia a s kým sa stretávajú. Podla režiséra majú zastupovat lyrickú rovinu Gogolovho románu a „opísat s láskou celé Rusko, aké bolo, aké bude a aké je“, no na druhej strane predstavujú

${ }^{28}$ SHAKESPEARE, W. Hamlet. [online]. [cit. 14. 4. 2019]. Dostupné na internete: https://cloud5.edupage. org/cloud/William-Shakespeare---Hamlet.pdf?z\%3Ar4775gKnrpQOCn60fF\%2Bm8XWGZpiFmmZgu1CKxzH2A5IozkdUrUA0Uz9QEpDcNY8Q. Bratislava : HEVI. 1994, s. 71.

${ }^{29}$ BUTUSOV, J. In ABAKŠONOK, N. - CAREVSKAJA, J. (eds.). Zolotaja maska. Rossijskaja nacional'naja teatral'naja premija i festival. 25. [Bulletin k festivalu]. Moskva: Zolotaja maska. Rossijskaja nacional'naja teatral'naja premija i festival', 2019, s. 45.

${ }^{30}$ Poisk (Hladanie), Lesosibirsk, premiéra 24. 9. 2017. 


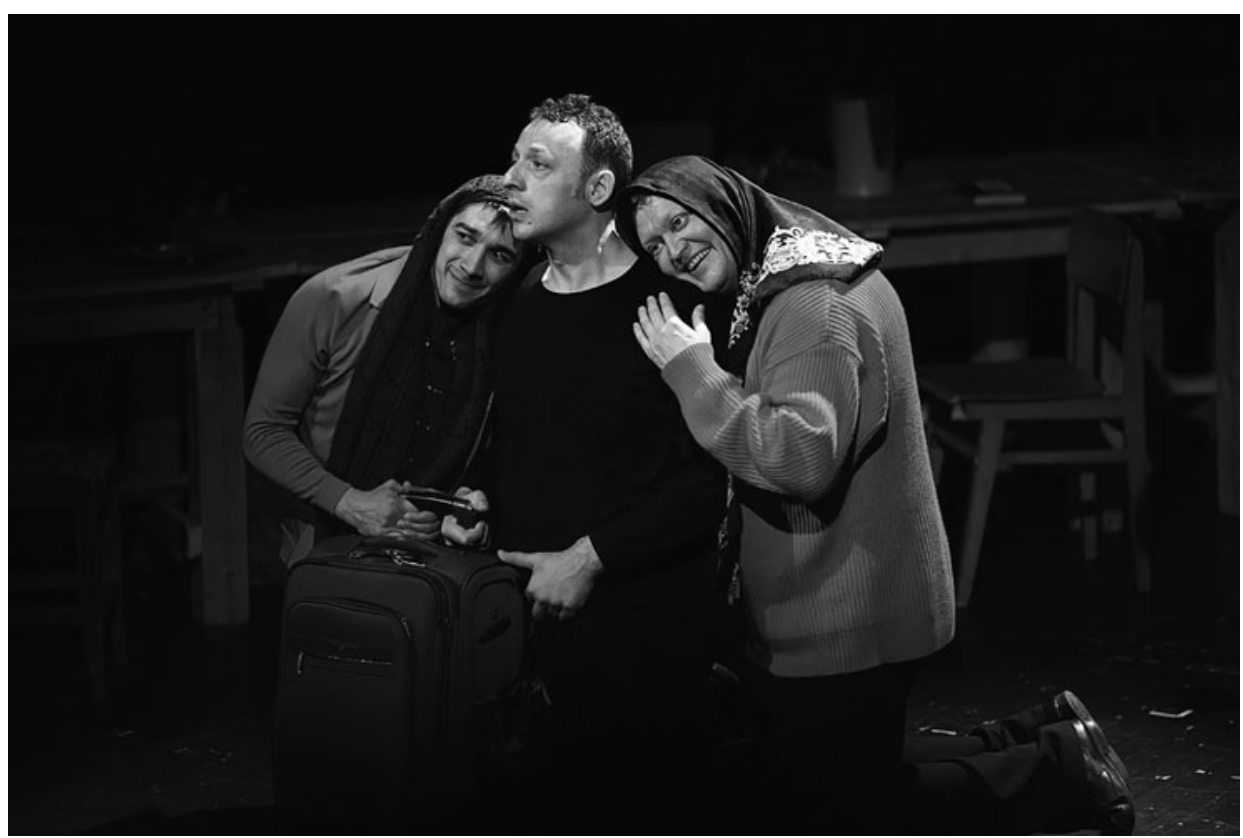

Nikolaj Gogol': Mŕtve Duše. Poisk, Lesosibirsk, premiéra 24. 9. 2017. Réžia Oleg Lipoveckij. Foto tlačové oddelenie festivalu Zlatá maska 2019. Snímka Dmitrij Dubinskij.

„kruté, neobjektívne a vel’mi smiešne napodobňovanie ruských charakterov a ruskej spoločnosti“. ${ }^{31}$

Podobne ako Mŕtve duše, aj Dostojevského Idiot v réžii Maxima Didenka ${ }^{32}$ je koncipovaný ako pantomimická klauniáda dvoch hercov a jednej herečky s nalíčenými tvárami a zbavenými pohlavia. Z postáv Dostojevského príbehu sa stávajú klaunmi na točiacej sa točni s domom - maringotkou, na ktorej hrajú svoje divadlo a okolo ktorej ,„jazdia“" po krajine na troch hojdacích koňoch. Donqichotovský príbeh o chorom kniežati Myškinovi a jeho snahe získat lásku, ktorá môže spolu s dobrom zmenit’ svet, sprevádza len niekol'ko citátov z románu, predovšetkým o povahe ruského národa a filozofických otázkach jeho budúcnosti.

Je zrejmé, že divadelní tvorcovia naliehavo reagujú na krízu tradičných hodnôt, spoločenských či náboženských rituálov, snažia sa oslobodit’ od stereotypov a nátlaku okolitého sveta zameraného na úspech a výkon. Ako sa ukazuje, každá generácia potrebuje svojho „idiota“. Tí súčasní však s veternými mlynmi bojujú po svojom. Poznačení predchádzajúcou sovietskou érou, v ktorej vyrastali ich rodičia, a paralelne s tým poznačení dnešnou modernou dobou, majú skôr vlastnosti antihrdinov. Chýbajú im morálne hodnoty, na ceste za vlastným štastím neváhajú porušovat pravidlá a dopúštat’ sa zločinov. Doba je opät krutá, a tak sa stávajú krutými aj oni. Ako

${ }^{31}$ LIPOVECKIJ, O. In ABAKŠONOK, N. - CAREVSKAJA, J. (eds.) Zolotaja maska. Rossijskaja nacional'naja teatral'naja premija i festival'. 25. [Bulletin k festivalu], s. 77.

32 Teatr Nacij (Divadlo Národov), Moskva, premiéra 16. 12. 2015. 


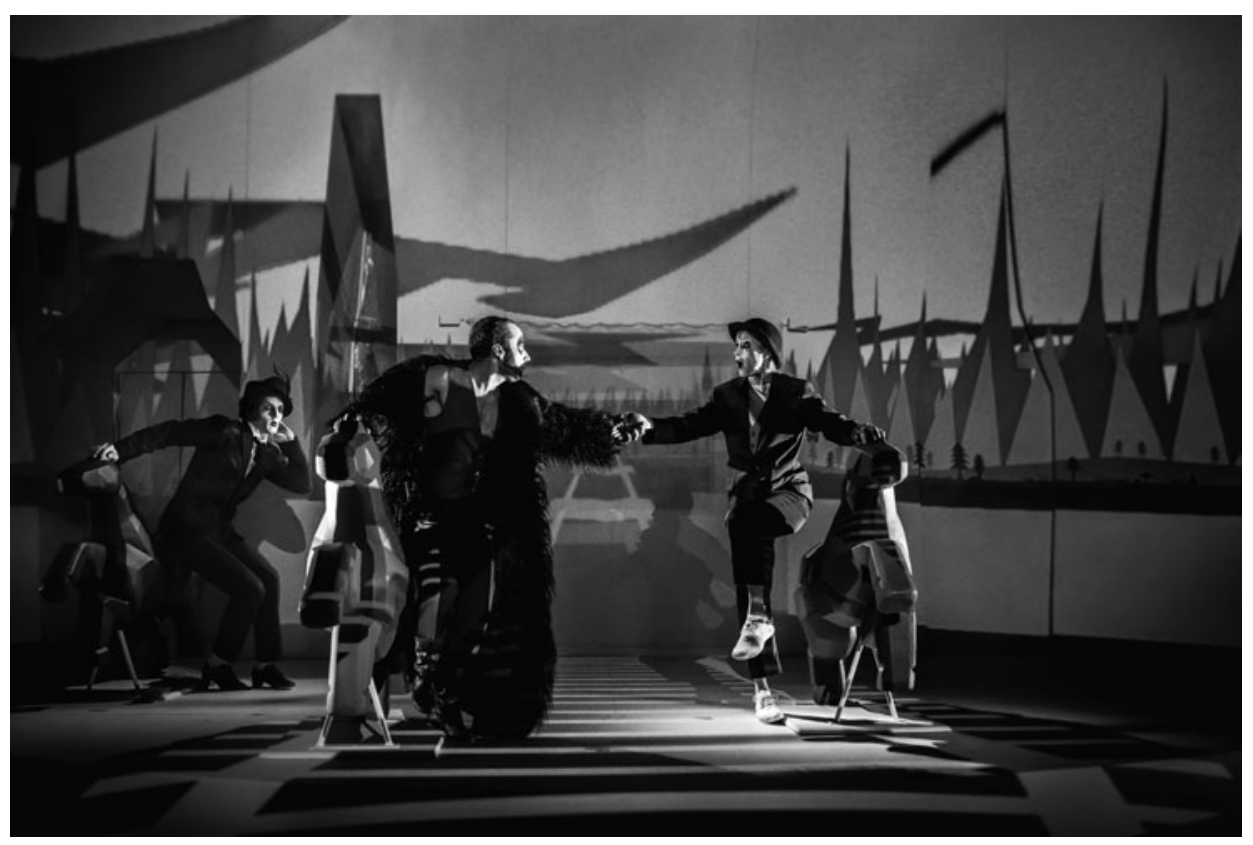

Fiodor Dostojevskij: Idiot. Teatr Nacij, Moskva, premiéra 16. 12. 2015. Réžia Maxim Didenko. Foto tlačové oddelenie festivalu Zlatá maska 2019. Snímka Ira Pol’arnaja.

napríklad učitel' filozofie Sergej Romanovič v hre bieloruského dramatika Andreja Ivanova S_učilišča (Z_učilišt’a) $)^{33}$, ktorý zvedie doňho zamilovanú študentku Taňu, starajúcu sa o invalidného otca, len preto, aby to nahral a zavesil na internet. Chce totiž vyhrat' stávku, ktorú v opitosti uzatvoril, získat’ Mac Book, dostat’ sa do klubu kamarila (špan. camarilla) a otvorit’ si nové možnosti v postupe kariéry. Nepočíta s tým, že sa Tani nebude vediet’ zbavit'. Pozná totiž jeho tajomstvo, ktorým ho vydiera - vie, že v mladosti s kamarátmi nechtiac zabili muža a potom ho zahrabali v lese. Taňa neberie do úvahy, že ich vztah so Seriožom je spoločensky neprijatelný. Jej láska sa mení na posadnutost'. Ked’ Serioža zistí, že dievča, ktoré sa mu zdalo naivné, v detstve pre zábavu upal'ovalo mačky, stáva sa pre neho "sukou“, na čo odkazuje aj názov inscenácie - „S_učilišča“. Forma jeho zápisu sa odvoláva na fenomén sociálnych sietí a virtuálnej reality, ktorá mladých l'udí pohlcuje natol’ko, až strácajú schopnost̉ rozlišovat' ju od skutočnosti. Akoby to nerozlišoval ani Serioža, ktorý sa rozhodne uskutočnit’ absurdný návrh Taninho priatela, prepusteného z väzenia, na zabitie Tani, čo má byt jediný spôsob oslobodenia sa od nej. Príbeh, ktorý je krutou sondou do duše mladých l’udí prežívajúcich „,shakespearovské” vášne“"34, rozohral režisér Semion Serzin so značnou dávkou trpkého humoru a irónie. Herci miestami

${ }^{33}$ Teatr im. A. S. Puškina-filial (Divadlo A. S. Puškina-filiálka), Moskva, premiéra 20. 1. 2018. Hra vznikla v roku 2016 v rámci Medzinárodného dramatického laboratória v Minsku.

${ }^{34}$ DŽUROVA, T. [online]. [cit. 11. 4. 2019]. Dostupné na internete: http://teatrpushkin.ru/plays/s_uchilischa. 


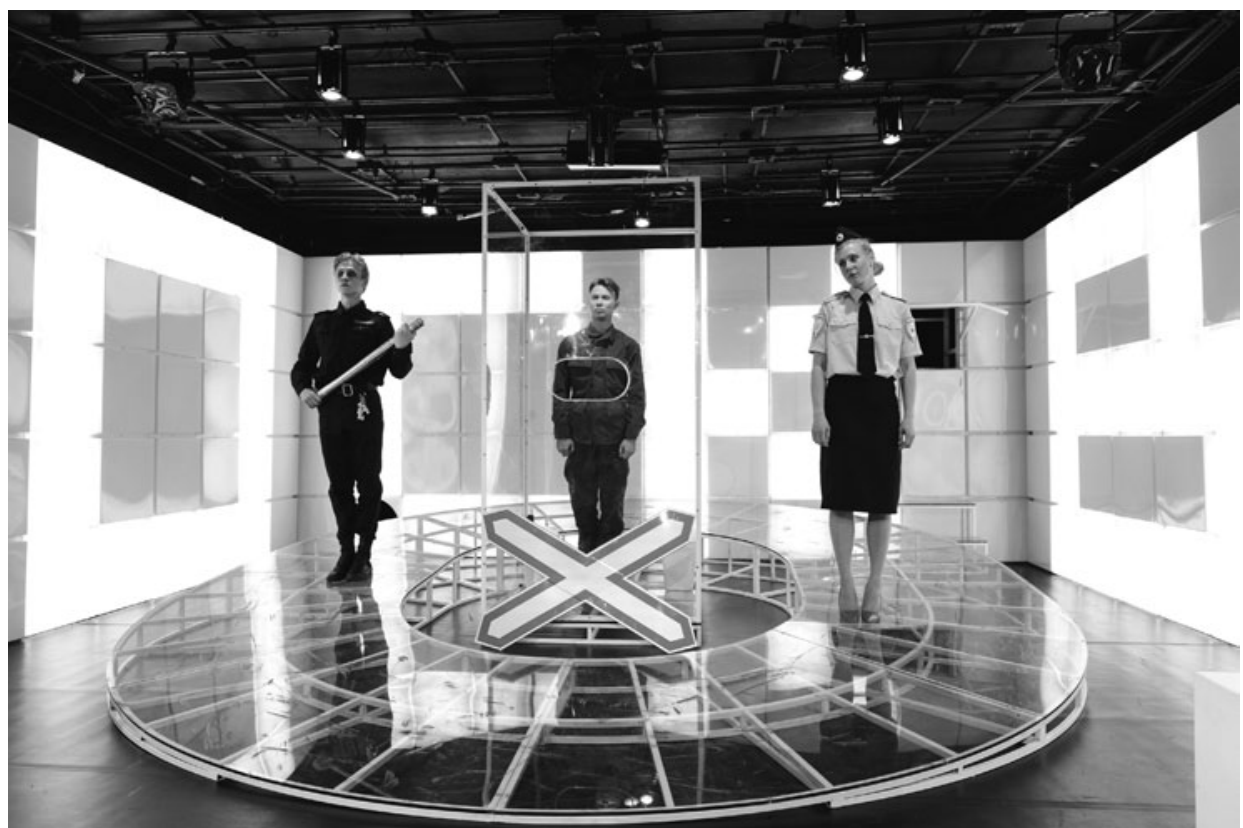

Dmitrij Danilov: Človek z Podolskka. Praktika, Moskva, premiéra 21. 9. 2018. Réžia Marina Brusnikinová. Foto tlačové oddelenie festivalu Zlatá maska 2019. Snímka Alexander Kurov.

vystupujú z rol a vytvárajú komornú kapelu spievajúcu piesne. Niektoré časti deja sú premietané ako videonahrávky na plátne, takže výsledný tvar je kombináciou divadla, filmu a koncertu.

Ďalší typ antihrdinu je voči okoliu i vlastnému životu apatický, vyhorený. Nemyslí na budúcnost', vlastne s ňou ani nepočíta. V inscenácii dvoch jednoaktoviek súčasného autora Dmitrija Danilova Čelovek iz Podol’ska (Človek z Podol'ska) a Serioža očeň tupoj (Serioža je strašne tupý) hranej pod výstižnou anotáciou „Psychologická inštalácia paradoxného príbehu o súčasnom človeku“"35, predstavila režisérka Marina Brusnikinová dvoch nihilistických mladých mužov, ktorí akoby boli jedným.

Mladý muž v Človeku z Podol’ska má prácu, hudobnú kapelu, priatel'ku, ale nič z toho ho nenapíňa. Nie je schopný vidiet prednosti svojho mesta, nemá k nemu vzt’ah a nevenuje mu žiadnu pozornost'. Pre tieto dôvody je zatknutý a držaný na policajnej stanici. Predstavitelia verejnej moci pod vedením mladej policajtky majú prostredníctvom fyzických i mentálnych cvičení zmenit jeho spôsob nazerania na svet a ukázat’ mu krásu, ktorá ho podl'a nich obklopuje. Na konci terapeutického sedenia u policajtov-psychológov mu je doručená záhadná zásielka v podobe hnedej škatule. Tento balík je hlavným predmetom aj v jednoaktovke Serioža je strašne tupý. V nej traja poslíčkovia z Akadémie doručenia prinesú tridsatročnému programátorovi zásielku, ktorú si neobjednal. Odovzdat’ mu ju však môžu až po spoločne strávenej hodine. Práve to je totiž ich poslanie - príst’ a byt’ s človekom, spoznat' ho, pomôct' mu

${ }^{35}$ Praktika (Prax), Moskva, premiéra 21. 9. 2018. 
v akejkolvvek veci, aj ho podla potreby operovat’ či pochovat'. Seriožovi rozprávajú príbehy svojich "klientov“ a zároveň mu kladú otázky o jeho živote. Rovnako ako policajti v Človeku z Podol’ska, aj oni mu chcú objasnit’ krásu života a pravé hodnoty, pričom kladú dôraz na rodinu. Serioža v nich budí pohoršenie tým, že ešte nemá deti, hoci je už ženatý s interiérovou dizajnérkou Mašou. Aj ona prichádza domov z práce a návštevu pohostí čajom, ako pravá japonská gejša. Maša je Seriožovým opakom, poslíčkovia oceňujú jej aktívnost’ a činorodost'. Po uplynutí hodinového limitu, ktorý od začiatku predstavenia odpočítavajú digitálne hodiny, poslíčkovia odovzdajú Seriožovi zásielku a odchádzajú. Zdá sa, že je v nej niečo živé. Maša ho okamžite donúti íst’ škatul'u vyhodit’ do kontajnera. Serioža nechce, ale napokon súhlasí. Kým je preč, Maša nadáva, aký je „strašne tupý“. Serioža sa vracia a priznáva, že nedokázal škatul'u vyhodit', a tak ju položil k vedlajšiemu vchodu.

Každá jednoaktovka sa odohráva v inej sále divadla, pričom diváci sú rozdelení na dve skupiny, takže každá ich vidí v inom poradí, čo má vplyv na ich interpretáciu. Životy hrdinov majú dat’ do poriadku verejné zložky, ktoré aj kedysi navštevovali l'udí, no rozhodne nie z altruistických dôvodov. Hra tak vyznieva ako absurdná paródia totemov bývalého režimu, ktoré sa dnes majú premenit na pozitívne symboly a rozveselit' divákov. Vzniká alternatívna prítomnost', v ktorej majú verejní činitelia nové, pre súčasný svet prospešné poslanie. Vykonávajú ho však s rovnakým fanatizmom ako ich predchodcovia a taktiež využívajú pre svoj ciel' rovnakú techniku - výsluch. Mnohé z otázok, ktoré dostávajú protagonisti inscenácie, majú pred jej začiatkom zodpovedat’ aj diváci. Zosumarizovanie výsledkov tejto ankety - prieskum súčasného ruského človeka - si môžu prečítat po skončení predstavenia na obrazovke vo foyeri. Do hry sú zainteresovaní aj počas prestávky, ked' ich herci učia spievat' hymnu Moskvy a dávajú im kvíz o znalostiach Ruska. Slovami tvorcov, „divák sa ocitá v priestore totálnej inštalácie, kde sa stáva súčasne pozorovatel’om i objektom pozorovania“"36.

\section{Záver}

Inscenácie predstavené v štúdii by sa dali rozdelit do troch tematických blokov (1) utopické námety, (2) revitalizácia pamäte a (3) inovatívne spracovania klasiky až po hl'adanie nových hrdinov v súčasnej dráme. Nie je však možné tvrdit', že by to boli jediné záujmy divadelných tvorcov. Tematická paleta inscenácií v ruskom divadle je vel’mi široká, pričom každá z tém je spracovaná mnohorakými spôsobmi. Ich dominantným spoločným prvkom je zámer tvorcov vypovedat' o súčasnom stave Ruska a jeho obyvatel'och. S najväčšou krajinou sveta a jej históriou sa totiž spája vel'ké množstvo mýtov, s ktorými musia jej občania bojovat’ nielen pred okolitým svetom, ale aj medzi sebou a najmä každý so sebou samým. Tvorcovia sa preto usilujú tieto mýty dekonštruovat', obnažovat', a tak sprostredkovat’ pravdu. Pri tom siahajú po najmodernejších výrazových a komunikačných prostriedkoch - od vizuálne atraktívnych projekcií a prepracovaných efektov, cez odvážne až provokačné koncepcie spájajúce divadelné tradície so súčasnými interpretačnými možnostami, až po najrôznejšie experimenty. Samozrejme, to vplýva aj na prácu hercov, ktorí sa ukazujú

\footnotetext{
${ }^{36}$ masterbrus.com. [Anotácia k inscenácii]. [online]. [cit. 12. 4. 2019] Dostupné na internete: https:// praktikatheatre.ru/events/chelovek-iz-podolska.
} 
herecky ako vel'mi flexibilní a prispôsobiví. V niektorých prípadoch (najmä v experimentálnych inscenáciách) je až zarážajúca oddanost' interpretov idei režiséra. Svedčí to o povahe súčasného ruského divadla, ktoré sa už dlhšie ukazuje ako výrazne režisérske. Silné osobnosti, akými sú Kirill Serebrennikov, Konstantin Bogomolov, Jurij Butusov, Andrej Mogučij, Maxim Didenko, Michail Ugarov a d’alší, predstavujú v divadelnom prostredí obdobu hereckých hollywoodskych hviezd, s množstvom fanúšikov a nasledovatelov, ktorí sa medzi sebou delia až na jednotlivé klany. Azda aj preto sa dá v súčasnom ruskom divadle vnímat’ nová tendencia - úsilie poskytovat’ väčší priestor mladým divadelníkom. Aj tí sa však usilujú od začiatku svojej kariéry vyhranit’ vlastný originálny režijný rukopis, pričom ich konceptuálnost’ ide niekedy na úkor inscenovaného diela a jeho kvality.

Rovnako pozoruhodnou ako otvorenost’ hercov voči fantázii režisérov sa javí byt’ tiež otvorenost' divákov, s akou prijímajú a reagujú na produkcie najrôznejšieho typu. Spolu s masívnym záujmom o divadlo rastie aj snaha inscenátorov o to, aby sa diváci stali súčastou predstavenia - aby sami na sebe pocítili tému hry, aby sa stala ich vlastnou a aby nad ňou uvažovali aj po odchode z divadla. Interaktivita - nielen fyzická, ale aj v zmysle emočnej reakcie diváka - je v dnešnom ruskom divadle rovnako podstatná ako jeho interdisciplinarita. Predstavuje aktívny spoločenský nástroj, ktorým sa umelci usilujú vzkriesit’ strácajúce sa, či dokonca už stratené hodnoty - osobné i národné. Otázkou ale zostáva, či ich tvorcovia dokážu jasne definovat’ a publikum správe prečítat'.

\section{CONTEMPORARY RUSSIAN THEATRE: MEMORIES OF THE FUTURE}

\section{Zuzana SPODNIAKOVÁ}

The year 2019 was declared the Year of the Theatre in Russia. The theatre not only maintains its important position here, but it is also an increasingly active tool for communication between creators and the public. In this context, the study focuses on the distinctive themes and forms of contemporary Russian theatre. It reveals the modern developmental tendencies of Russian theatre culture, which reflect both past and present and raise an urgent question about the future - personal, national and world wide. Through selected productions and theatrical personalities presented at the Golden Mask Festival 2019, the author captures the new approaches of creators to classical dramatic and prosaic works, as well as a way of reflecting on Russia's history, its national symbols and myths in production texts by contemporary Russian playwrights.

Táto práca bola podporená Agentúrou na podporu výskumu a vývoja na základe zmluvy APVV č. 15-0764 - Slovenské divadlo a súčasná európska divadelná kultúra - kontinuita a diskontinuita. 


\section{LITERATÚRA}

ABAKŠONOK, Natalia - CAREVSKAJA, Jelizaveta (eds.). Zolotaja maska. Rossijskaja nacionalnaja teatral'naja premija i festival'. 25. [Bulletin k festivalu]. Moskva : Zolotaja maska. Rossijskaja nacional'naja teatral'naja premija i festival', 2019. $313 \mathrm{~s}$.

DJ Pavel. [Anotácia k inscenácii]. [online]. [cit. 21. 4. 2019]. Dostupné na internete: https://teatrpost.timepad.ru/event/978679/.

DŽUROVA, Tatiana. [online]. [cit. 11. 4. 2019]. Dostupné na internete: http://teatrpushkin.ru/ plays/s_uchilischa.

L'VOVA, Marija - CHALIZEVA, Marija. (eds.). Kritiki - ob istorii "Zolotoj maski“ i novejšego rossijskogo teatra. Moskva : Moskva : Zolotaja maska. Rossijskaja nacional'naja teatral'naja premija i festival', 2019, $130 \mathrm{~s}$.

masterbrus.com. [Anotácia $\mathrm{k}$ inscenácii]. [online]. [cit. 12. 4. 2019] Dostupné na internete: https://praktikatheatre.ru/events/chelovek-iz-podolska.

Tri tolst'aka. [Anotácia k inscenácii]. [online]. [cit. 11. 4. 2019]. Dostupné na internete: https://bdt. spb.ru/спектакли/три-толстяка/.

Rodina. [Bulletin k inscenácii]. Moskva : Centr imeni Vs Mejerchol’da, 2017. Nestránkované.

Rodina. [Anotácia k inscenácii]. [online]. [cit. 17. 4. 2019]. Dostupné na internete: http://meyerhold.ru/rodina/.

SAVITSKAJA, Alexandra - ARAPOVA, Tamara. (eds.). Russian Case Golden Mask Festival 2019 [Bulletin k Russian Case]. Moskva : Zolotaja maska. Rossijskaja nacionalnaja teatralnaja premija i festival', $2019.67 \mathrm{~s}$.

SHAKESPEARE, William. Hamlet. Bratislava : HEVI. 1994, 160 s. [online]. [cit. 14. 4. 2019]. Dostupné na internete: https://cloud5.edupage.org/cloud/William-Shakespeare---Hamlet.pdf?z\%3Ar4775gKnrpQOCn60fF\%2Bm8XWGZpiFmmZgu1CKxzH2A5IozkdUrUA0Uz9QEpDcNY8Q.

Zuzana Spodniaková

Ústav divadelnej a filmovej vedy CVU SAV

Dúbravská cesta 9

84101 Bratislava

e-mail: zuzana.spodniakova@savba.sk 